東北地理 Vol. 37 (1985) pp. 133 134

Ann. Tohoku Geogr. Assoc.

\title{
秩父山地破風山における岩塊斜面上に 成立する低木群落
}

清 水長 正*。鈴木北告**

秩父山地のハイマッ群落は，金峰山から国師岳に かけての標高 $2,500 \mathrm{~m}$ 前後の稜線付近のところどこ ろに分布することが知られているが(鈴木, 1977 ; 中 込，1982)，その稜線高度よりも低い破風山 $(2,317.7$ m) の山頂付近にもハイマッの存在が指摘されてい る(木暮, 1914)。本報告は, 亜高山帯に属する破風 山付近にハイマッを含む低木群落が成立する理由 を，岩塊斜面という土地条件から考察する。

破風山北西側斜面の標高 $2,050 \sim 2,300 \mathrm{~m}$ には, 亜 高山針葉樹林に囲まれた低木群落が存在する（第 1 図)。主にコメッガ, ハイマッ, ネズコ, ハクサンシャ

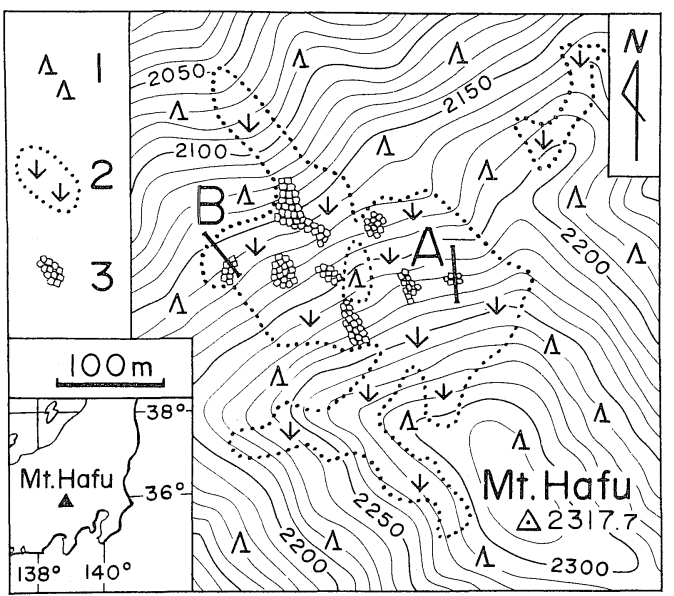

第 1 図破風山の低木群落の分布

1. 悪高山針葉樹林 2 . 低木群落 3 . 岩塊 地

（図中 A, B は第 2 図の位置を示す）
クナゲ, アズマシャクナゲで構成され, 群落高は $2 \mathrm{~m}$ 前後以下である。その中に樹高 $3 \sim 7 \mathrm{~m}$ のシラビソ, ヒメコマッ, カラマッが点在する。低木群落が成立 する斜面 (以下に低木群落斜面と呼ぶ) には, 長径 1 2.5 m のマトックスを欠く花崗岩の岩塊が厚 さ $3 \mathrm{~m}$ 以上堆積し, 斜面の一部には岩塊が露出する 岩塊地がみられる(第 1 図)。

第 2 図の $\mathrm{A}$ は無植生に近い岩塊地を含めた植 生・地形断面である。コメッガ, ネズコ, シャクナ

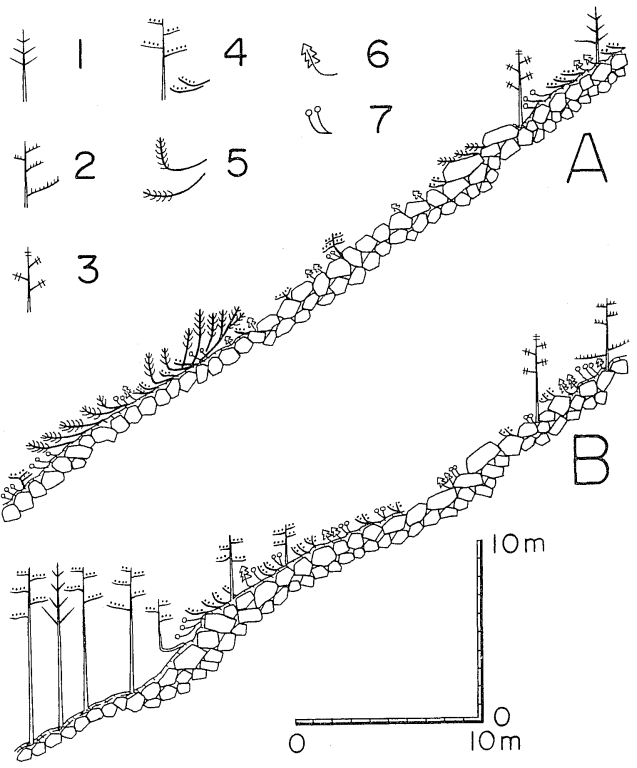

第 2 目岩塊斜面の植生・地形断面

1. シラビソ Abies veitchii 2. ヒメコマ ツ Pinus parviflora 3. カラマッ Larix leptolepis 4. コメッガ Tsuga diversifolia 5. ハイマッPinus pumila 6. ネズコ Thuja standishii 7. シャクナゲ類 Rhododendron 
ゲ類はいずれも根元が皃らくし，枝が叢生し，岩塊 を密に扣揖っている。ハイマッは岩塊地の周辺に以 下のような状態で生育している。岩塊地の下方では 密生していてハイマッ優占の小群落をつくり, ほふ くする生幹は長さ $7 \mathrm{~m}$ 以上に和よび, 高さ $3 \mathrm{~m}$ 近く まで伸び上る枝を含む多くの枝を派生していて，生 育は良好といえる。一方，岩塊地の上方や側方では 径 1 ～ $2 \mathrm{~m}$ 程度の広がりをもつ群落高 $40 \mathrm{~cm}$ 前後の 小群がわずか散生するのみで, 樹勢も良好ではない。 また，一部の岩塊地では枯死した長いほふく茎をさ らしている。このことは，過去に执いて現在よりも 広くハイマツ群落が成立していたことを示唆する。 破風山北西側斜面の低木群落は高山的景観を呈し てはいるが，ハイマッは局部的に小群をつくるにす ぎず構成樹種の萎とえどは亜高山針葉樹林と同じ種 類であるので，ハイマッ群落を主とする高山帯植生 とは異なったものといえる。

第 2 図の B は, 低木群落斜面の末端部の植生・地 形断面である。低木群落と亚高山針葉樹林の境界部 では, 岩塊が傾斜 $40^{\circ}$, 比高 $4 \mathrm{~m}$ の小崖をつくり, 低 木群落斜面の末端となっている。低木群落斜面の下 端部から側縁部にかけての地形は，このように打抒 むね低木群落側から亜高山針葉樹林側へ急に下降す るような形態を示す。しがって低木群落斜面は, 表 面は平滑ではあるものの長大な舌状地形とみなすこ とができる。ところで，清水（1983）は空中写真判
読から破風山付近の標高 $2,000 \mathrm{~m}$ 以上に最終氷期に 形成された岩塊斜面（化石周水河斜面）が分布する ことを認めている。低木群落斜面はその分布範囲内 に存在することから，最終氷期の一時期に形成され た周水河性岩塊斜面と推定される。

低木群落斜面の範囲と岩塊斜面の範囲が一致する 状態は，筆者らが金峰山で報告した，岩塊斜面上に ハイマッ群落が成立しその岩塊斜面末端に森林限界 が位置する状態（鈴木・清水，1982）に酷似する。一 般に岩塊斜面は，巨大な岩塊が累積していて土壌が 形成されにくく，高木の生育には不適とみなされて いる。破風山北西側斜面でも垂直分布上で亜高山針 葉樹林の発達が十分可能な高度帯にありながら, 岩 塊斜面の存在によって森林の発達が抑制され，低木 群落が成立していると考えられる。

（1985年 2 月 19 日 受理）

\section{文献}

木暮理太郎 (1914)：秩父の奥山. 山岳, 9, 235 271. 清水長正 (1983): 秩父山地の化石周水河斜面. 地理評, $56, \quad 521 \sim 534$.

鈴木由告 (1977)：秩父金峰山の垂直分布に関する一考 察。植物之自然, 11-4, 11 17.

鈴木由告・清水長正 (1982): 秩父山地金峰山における 化石周水河地形からみた森林限界. 地理予， 21 , $266 \sim 267$.

中込司郎 (1982)：山梨県の樹木.山梨.

\section{Scrub Community Covers Block Slope on Mt. Hafu in the Chichibu Mountains, Central Japan}

\section{Chōsei SHIMIZU and Yoshitsugu SUZUKI}

